BIOMEDICAL AND BIOSOCIAL ANTHROPOLOGY
Official Journal of the International Academy
of Integrative Anthropology
journal homepage: http://bba-journal.com

\title{
Age-related features of tongue arteries remodeling in the experimental animals
}

Hnatiuk M. S., Bodnarchuk I. V., Tatarchuk L. V., Hasiuk P. A.

State Higher Educational Establishment "I. Horbachevsky Ternopil State Medical University, Ministry of Health of Ukraine"

\author{
ARTICLE INFO \\ Received: 7 September, 2018 \\ Accepted: 1 November, 2018 \\ UDC: $616.145 .19-092-02.616-001.17$
}

\section{CORRESPONDING AUTHOR}

e-mail: hnatjuk@tdmu.edu.ua Hnatiuk M. S.
The structural and functional features of the tongue attract the attention of researchers who are often interested in the peculiarities of the structural organization of its arterial bed, which plays an important role in blood supply and morphogenesis of the organ in various injuries. The aim of the research was to study the age-specific features of remodeling of tongue arteries in the experimental animals. The materials of the study were the arterial vessels of the tongue of 30 laboratory albino male rats, which were under normal vivarium conditions. The test animals were divided into two groups. The 1 st group consisted of 15 intact, practically healthy animals at the age of 8 months, the $2 n d-15$ intact rats at the age of 24 months. The euthanasia of experimental animals was carried out by bloodletting under conditions of thiopental-sodium anesthesia. The pieces were cut from the middle part of the tongue and fixed in a $10 \%$ neutral solution of formalin. The indicated pieces of tongue were carried out through the ethyl alcohol of increasing concentration and placed in paraffin blocks. After deparaffinization microtome sections 5-7 microns thick were stained with hematoxylin-eosin, by van Gizon, Mallory, Weigert, and toluidine blue. The morphometry of the arteries of the middle (external diameter 51-125 microns) and small calibers (outer diameter - 26-50 microns) of the tongue was carried out. The morphometry of the arteries of the tongue was determined by their external and internal diameters, the thickness of the mediums and adventitia, the height of the endothelial cells, their nuclei, the nuclear-cytoplasmic relations in the endothelial cells, the Kernogan index, and the relative volume of the damaged endothelial cells. Quantitative indicators were processed statistically. The analysis of the obtained morphometric parameters revealed that with the age the arteries of the small caliber have changed more. The outer diameter of arteries of small caliber tongue of the 24month-old albino rats has increased only for $1.2 \%$ and the clearance has decreased by 4.4\%. An increase in the outer diameter of the examined vessels and a decrease in their lumen led to a change in the Kernogan index, which with a statistically significant difference $(p<0.01)$ has decreased by $11.8 \%$. The thickness of the mediums of these tongue arteries of the 24-month-old albino rats, has increased by $7.5 \%$ and the thickness of the adventitia by $6.2 \%$. During the research in the experimental conditions, the height of the endothelial cells of the examined vessels has decreased by $2.4 \%$, and the diameter of their nuclei - by 3.3\%. There was no significant difference between the nuclear-cytoplasmic ratio in the endothelial cells of the studied vessels in the tongue of 8-month and 24-month-old white rats, which indicated a stability of structural cellular homeostasis. The relative amount of damaged endothelial cells in the studied experimental conditions in the arteries of the middle caliber has increased by $17.3 \%$, and of the minor caliber - by $23.7 \%$, which is explained by their age apoptosis. The obtained results testify that with the age there is a structural reorganization (remodeling) of predominantly arteries of the small caliber of the tongue, which is characterized by thickening of their walls, narrowing of the lumen, increasing of the thickness of the mediums and adventitia. The age-related decrease of the Kernogan index of the examined vessels indicates a decrease in their physiological capacity and deterioration of the blood supply of the organ. The morphometric parameters of endothelial cells and their nuclei are altered with the age, maintaining structural cellular homeostasis. The relative amount of damaged endothelial cells in the examined vessels is also increased with 
the age. Proven, the degree of age-related structural rearrangement of the arterial bed of the tongue depends on the caliber of the vessels.

Keywords: age features, rats, tongue, arteries, remodeling, morphometry.

\section{Introduction}

The structural and functional features of the tongue attract the attention of researchers these days. The tongue belongs to the initial part of the gastrointestinal tract and throughout its life carries a multifaceted function. The tongue is always drawn into the pathological process with various diseases of the digestive system. It is known that the morphofunctional features of the specified organ and their changes in pathological conditions depend on the morphology of the vascular bed [1, 4, 13, 19, 20].

In recent years, researchers are increasingly interested in the peculiarities of the structural organizations of the tongue, its vascular bed and their changes in various pathological conditions [1, 3, 5, 7, 10]. The arterial bed of organs plays an important role in blood supply and their morphogenesis with various injuries [5, 8, 16, 18]. At the same time, the quantitative morphological study of the features of the age-related remodeling of the arterial bed of the tongue is not complete, which determines the relevance of this research.

The literature does not cover the issues of microcirculatory disorders in patients with desquamative and atrophic changes back of the tongue, the relationship between the frequency of occurrence and the state of oral hygiene and immune disorders is not described. In this regard, dentists are faced with the problem of choosing effective ways of this pathology treatment. The foregoing determines the relevance of the detailed study of histological and ultrastructural changes and vascular disorders by developing using common clinical methods and with the creation new experimental models [13].

The aim of the research - to study the age-specific features of remodeling of tongue arteries in experimental animals.

\section{Materials and methods}

The materials of the study were the arterial vessels of the tongue of 30 laboratory albino male rats, which were under normal vivarium conditions. The test animals were divided into two groups. The 1st group consisted of 15 intact, practically healthy animals at the age of 8 months, the 2nd 15 intact rats at the age of 24 months.

The euthanasia of experimental animals was carried out by bloodletting under conditions of thiopental-sodium anesthesia. The pieces were cut from the middle part of the tongue and fixed in a $10 \%$ neutral solution of formalin. The indicated pieces of tongue were carried out through the ethyl alcohol of increasing concentration and placed in paraffin blocks. After deparaffinization microtome sections 5-7 microns thick were stained with hematoxylin-eosin, by Van Gieson, Mallory, Weigert, and toluidine blue [9, 14].

The morphometry of the arteries of medium (outer diameter 51-125 microns) and small calibers (outer diameter - 26-50 microns) of the tongue was performed [4, 15, 17]. The experiments and euthanasia of experimental animals were conducted in compliance with the "General Ethical Principles of Animal Experiments" adopted by the First National Congress on Bioethics (Kyiv, 2001) and in accordance with the "European Convention for the Protection of Vertebrate Animals Used for Research and Other Scientific Purposes" [12].

At the morphometry of the arteries of the tongue, their external (DE) and internal (DI) diameters, medial thickness (TM) and thickness of the adventium (TA), height of endothelial cells (HE), their nuclei (DN), nuclear-cytoplasmic relations in endothelial cells, Kernogan index $(\mathrm{IK})$, the relative volume of damaged endothelial cells (VODE) were estimated [2, 11]. The morphometry of small-caliber arteries of the tongue was performed using a light microscope Olimpus BX-2 with a digital video camera and a software package "Video test 5.0" and "Video size 50". Morphological quantitative indicators were processed statistically. The processing of the received quantitative parameters was carried out in the department of systemic statistical research of the secondary educational institution "Ternopil State Medical University named after I. Y. Horbachevsky of the Ministry of Health of Ukraine" in the software package "Statistica". The difference between the comparative values was determined by the Mann-Whitney and Student criteria [6].

\section{Results}

The quantitative morphological indices obtained as a result of the study are presented in Table 1.

The comprehensive analysis of the obtained morphometric parameters of the arteries of the tongue revealed that some of them in the older-aged group of the experimental animals were significantly changed. Thus, the outer diameter of the arteries of the middle caliber has increased by $0.7 \%$, the thickness of the mediums - by $4.1 \%$ $(p<0.05)$, the thickness of the adventitia - by $8.3 \%(p<0.01)$, the relative amount of damaged endothelial cells by $17.3 \%$ $(p<0.01)$, and their lumen has decreased by $2.4 \%(p<0.05)$, Kernogan index - by $6.3 \%(p<0.01)$.

The degree of remodeling of the small-caliber arteries of the tongue of 24-month-old albino rats, was more pronounced in comparison with the previous vessels. Thus, the outer diameter of the arteries of the small caliber of the tongue has increased from $41.10 \pm 0.54 \mu \mathrm{m}$ to $41.60 \pm 0.51$ $\mu \mathrm{m}$, that is, only $1.2 \%$. The internal diameter of the investigated vessels has decreased from 15.80 0.12 microns to $15.10 \pm 0.12$ microns, that is, by $4.4 \%$. The given quantitative morphological indicators of internal diameters of small caliber arteries of young and old animals statistically 
Table 1. Morphometric characteristics of the arteries of the tongue of albino rats $(\mathrm{M} \pm \mathrm{m})$.

\begin{tabular}{|c|c|c|}
\hline \multirow{2}{*}{ Indicator } & \multicolumn{2}{|c|}{ observation group } \\
\hline & 1st & 2nd \\
\hline \multicolumn{3}{|c|}{ Arteries of medium caliber } \\
\hline DE, microns & $84.50 \pm 0.60$ & $85.10 \pm 0.70$ \\
\hline DI, microns & $46.30 \pm 0.36$ & $45.20 \pm 0.32^{*}$ \\
\hline TM, microns & $19.50 \pm 0.21$ & $20.30 \pm 0.24^{*}$ \\
\hline TA, microns & $12.28 \pm 0.15$ & $13.30 \pm 0.18^{* \star}$ \\
\hline $\mathbb{K}, \%$ & $30.10 \pm 0.40$ & $28.20 \pm 0.30^{* *}$ \\
\hline HE, microns & $6.420 \pm 0.120$ & $6.300 \pm 0.120$ \\
\hline DN, microns & $2.450 \pm 0.020$ & $2.400 \pm 0.020$ \\
\hline NAC & $0.146 \pm 0.003$ & $0.145 \pm 0.004$ \\
\hline VODE, \% & $1.960 \pm 0.050$ & $2.300 \pm 0.060^{* *}$ \\
\hline \multicolumn{3}{|c|}{ Arteries of small caliber } \\
\hline DE, microns & $41.10 \pm 0.54$ & $41.60 \pm 0.51$ \\
\hline DI, microns & $15.80 \pm 0.12$ & $15.10 \pm 0.12^{* *}$ \\
\hline $\mathrm{TM}$, microns & $13.30 \pm 0.12$ & $14.30 \pm 0.12^{* *}$ \\
\hline TA, microns & $5.650 \pm 0.050$ & $6.000 \pm 0.060^{* *}$ \\
\hline $\mathrm{IK}, \%$ & $14.80 \pm 0.18$ & $13.10 \pm 0.12^{* * *}$ \\
\hline $\mathrm{HE}$, microns & $6.350 \pm 0.040$ & $6.200 \pm 0.050^{*}$ \\
\hline DN, microns & $2.420 \pm 0.020$ & $2.340 \pm 0.020^{*}$ \\
\hline NAC & $0.145 \pm 0.003$ & $0.142 \pm 0.002$ \\
\hline VODE, \% & $2.150 \pm 0.020$ & $2.660 \pm 0.030^{\star \star \star}$ \\
\hline
\end{tabular}

significantly $(p<0.01)$ differ. An increase in the outer diameter of the studied vessels and a decrease in their lumen led to a change in the Kernogan index, which at the same time with a statistically significant difference $(p<0.01)$ has decreased from $14.80 \pm 0.18 \%$ to $13.10 \pm 0.12 \%$, that is by $11.5 \%$. The growth of the thickness of the mediums of the indicated arteries of the tongue of the 24-month-old albino rats, with $13.30 \pm 0.12 \mu \mathrm{m}$ to $14.30 \pm 0.12 \mu \mathrm{m}$ was observed. The given morphometric parameters statistically significantly differed $(p<0.01)$ and the last quantitative morphological index exceeded the previous by $7.5 \%$. The thickness of the adventitia of the arteries of the given tongue caliber in the 8month white rats was equal to $5.650 \pm 0.050 \mu \mathrm{m}$, and in animals of the older age group $-6.000 \pm 0.060 \mu \mathrm{m}$. A statistically significant $(p<0.01)$ difference was found between the given morphometric parameters. At the same time, the last quantitative morphological indicator exceeded the previous one by $6.2 \%$.

The experimental conditions also altered the height of the endothelial cells of the examined vessels. Thus, in the 1 st group of observation, the specified morphometric parameter was $6.350 \pm 0.040 \mu \mathrm{m}$, and in the 2nd $6.200 \pm 0.050 \mu \mathrm{m}$. The last quantitative morphological index was statistically significantly $(p<0.05)$ lower, comparing with the previous one by $2.4 \%$. The diameters of the nuclei of the studied cells also with a statistically significant difference $(p<0.05)$ have decreased from $2.420 \pm 0.020$ microns to $2.340 \pm 0.020 \mu \mathrm{m}$, that is, by $3.3 \%$.

It should be noted that the significant difference between the nuclear-cytoplasmic ratio in the endothelial cells of the examined vessels in the tongue of 8-month and 24-monthold white rats was not observed. The specified morphometric parameter was respectively $0.145 \pm 0.040$ and $0.142 \pm 0.020$.

The relative amount of damaged endothelial cells in the studied experimental conditions has changed. Thus, in the 1 st group of observations, the specified morphometric parameter equaled $2.150 \pm 0.020 \%$, and in the 2 nd group with a statistically significant difference $(p<0.001)$ has increased by $23.7 \%$ and reached $2.660 \pm 0.030 \%$.

\section{Discussion}

It is known that vascular endothelial cells play an important role in regulating vascular tone, homeostasis, inflammation, and also integrate reflex, humoral mechanisms and local processes. Endothelial cells synthesize biologically active substances that directly affect smooth myocytes of the arteries, causing vasodilation (nitric oxide, prostacyclin), or vasoconstriction (prostaglandin $\mathrm{H} 2$, endothelin). Under normal physiological conditions, these factors are in a state of dynamic balance. With an increase in the number of damaged endothelial cells, this balance is disturbed in the direction of vasoconstrictor factors. The leading role in the regulation of vascular tone plays nitrogen oxide (NO). Endothelial cell damage results in endothelial dysfunction, blockade of NO synthase, reducing of NO synthesis, activation of its degradation processes, and is accompanied by spasm, narrowing of the arterial lumen that supports and exacerbates hypoxia, which is complicated by edema, dystrophy and necrobiosis of cells and tissues $[16,18]$.

The conducted research and the obtained results testify that with the age there is a structural reorganization (remodeling) of predominantly arteries of the small caliber of the tongue, which is characterized by thickening of their walls, narrowing of the lumen, increasing of the thickness of the mediums and adventitia. The main reason for this is that they are in greater functional tension by regulating blood circulation [16]. The age-related decrease of the Kernogan index of the examined vessels indicates a decrease in their physiological capacity and deterioration of the blood supply of the organ. The morphometric parameters of endothelial cells and their nuclei are altered with the age, maintaining structural cellular homeostasis. The relative amount of damaged endothelial cells in the examined vessels is also increased with the age. The revealed evidence showed that despite the uneven spatial characteristics of the endothelial cells of small caliber arteries of the tongue and their nuclei in the mature albino rats and experimental animals of the elderly group, the structural cellular homeostasis in the studied cells was not violated [2, 18].

Despite structural changes, the arteries perform their 
function, which is confirmed by the stability of cellular structural homeostasis and the absence of pathological changes in the studied organ. At the same time, some researchers suggest that age-related arterial remodeling reduces the adaptive reserves and compensatory capabilities of organs that are more likely can be damaged by the effects of negative endogenous and exogenous factors $[5,14,19]$, which requires further in-depth research.

\section{References}

[1] Atamanchuk, O. V. (2011) The three-dimensional structure of the tongue papillae of rats is normal. Bulletin on Biology and Medicine, 2(2), 20-23.

[2] Avtadnilov, G. G. (2002). Basis of Quantitative Pathological Anatomy. M.: Medicine.

[3] Bavykina, T. Yu. \& Yefremova, O. A. (2011). Cavity - mirror of diseases of the internal organs. Scientific statements of Belgorod State University. Series: Medicine. Pharmacy, 10(105), 14, 236-238.

[4] Hearnden, V., Lomas, H., Macniel, S., Thornhill, M., Murdoch, C., Lewis, A., ... Battaglia, G. (2009). Diffusion studies of nanometer polymersomes across tissue engineered human oral mucosa. Pharm. Res., 26(7), 1718-1728. doi: 10.1007/ s11095-009-9882-6

[5] Herasymyuk, I. Ye., \& Fedorovych, O. A. (2013). Morfofunctional changes and spatial characteristics of the vascular bed of the tongue with its burns of different genesis in the experiment. Galician Medicinal Herald, 20(1), 26-29.

[6] Lapach, S. N., Gubenko, A. V., \& Babich, P. N. (2001). Statistical methods in medicobiological investigations Excell. K.: Morion.

[7] Latysheva, S. V., \& Budevskaya, T. V. (2015). Diagnostics of tongue pathology. Modern view. Modern dentistry, 1, 37-41.

[8] Lutskaya, I. K. (2015). Symptomatic and self diseases of the tongue. Medicine news, 3, 13-17.

[9] Maksymenko, P. T., Skrypnykova, T. P., \& Khmyl', T. A. (2008). Nomenclature, clinical classification of diseases. Changes in multius shell. Cavity of the mouth, lip and tongue. Ukrainian Dental Almanac, 4, 28-35.

[10] Modina, T. N., Shumskiy, A. V., \& Mamayeva, Ye. V. (2010). Diagnosis and treatment of various forms of descammative glossitis. The Bulletin of Modern Clinical Medicine, 3(1), 2632.

[11] Popel', S. L., Baskevych, O. V., Zhurakivs'kyy, V. M., Zhurakivs'ka, O. Ya., Mel'nyk, I. V., Krasnopol's'kyy, S. Z., \& Atamanchuk, O. V. (2017). Three-dimensional structure of the papillae of the tongue of rats in normal and experimental

\section{Conclusions}

Age features of remodeling of the arteries of the tongue are characterized by thickening of the wall, narrowing of their lumen, decreasing of the Kernogan index, decreased blood vessel capacity, increased apoptosis and deterioration of blood supply to the organ. The degree of age-related structural rearrangement of the arterial bed of the tongue depends on the caliber of the vessels.

diabetes mellitus (to the mechanism of development of diabetic glossitis). Regulatory Mechanisms in Biosystems, 8(1), 5865. doi: https://doi.org/10.15421/021711

[12] Reznikov, O. G. (2003). General ethical principles of experiments on animals. Endocrinology, 8(1), 142-145.

[13] Semenova, A. K., Yeroshenko, G. A., Hasyuk, N. V., \& Stakhanska, O. O. (2014). Morphofunctional characteristics of the epithelium of the mucous membrane of the tongue of rats are normal. Bulletin of Biology and Medicine, 2(2), 134137.

[14] Sorochinnikov, A. G., \& Dorosevich, A. Ye. (2007) Histological and microscopic techniques. M: Medicine.

[15] Sel'kina, A. B., Shepit'ko, V. I., Yeroshenko, G. A., \& Hnidets', V. A. (2010). Restoration of the local protective barrier of the rat language mucous sheet in the experimental conditions of experimental acute aseptic. World of Medicine and Biology, 4, 152-155.

[16] Shormanov, S. V., \& Kulikov, S. V. (2007). Histological and ultrastructural changers at experimental stenosis of pulmonary trunk at insuficsence. Morphology, 3, 46-50.

[17] Sultan, R. Ya., Pokotylo P. B., Hnidyk Yu. V., Mota O. M., \& Halyuk U. M. (2016). The reconstruction of the rat tounge hemomicrocirculatory stream in the dynamics of experimental diabetes mellitus. World of Medicine and Biology, 2(56), 195199.

[18] Tatarchuk, L. V., \& Hnatyuk, M. S. (2018). Morphometrical evaluation peculiarities structural reconstruction arteries of ileum at postresection portal hypertension. Achievements of clinical and experimental medicine, 2, 116-121. doi: 10.11603/ 1811-2471.2018.v0.i2.8442

[19] Yeroshenko, G. A., Semenova, A. K., \& Hasyuk, N. V. (2013). Transparency and structure of youth diseases in young age patients. World of Medicine and Biology, 3, 14-16.

[20] Zykeyeva, S. K., \& Bilisbayeva, M. O. (2018). Tongue and lips diseases of children and adolescents. Vestnik KazNMU, 1, 148-153.

\section{ВІКОВІ ОСОБЛИВОСТІ РЕМОДЕЛЮВАННЯ АРТЕРІЙ ЯЗИКА В ЕКСПЕРИМЕНТАЛЬНИХ ТВАРИН \\ Гнатюк М. С., Боднарчук І. В., Татарчук Л. В., Гасюк П. А.}

Структурно-фрункціональні особливості язика до сьогоднішнього дня привертають увагу дослідників, які часто цікавляться особливостями структурної організації його артеріального русла, що відіграє важливу роль у кровопостачанні та морфоогенезі органа при різних пошкодженнях. Мета дослідження - вивчити вікові особливості ремоделювання артерій язика в експериментальних тварин. Матеріалом дослідження були артеріальні судини язика 30 лабораторних білих щурів-самців, що знаходилися у звичайних умовах віварію. Дослідні тварини були розділені на 2-і групи. 1-а група нараховувала 15 інтактних практично здорових тварин віком 8 міс., 2-а - 15 інтактних шурів віком 24 міс. Евтаназія дослідних тварин здійснювалася кровопусканням в умовах тіопентал-натрієвого наркозу. 3 середньої частини язика вилучали шматочки, які фріксували у 10\% нейтральному розчині формаліну. Вказані шматочки язика проводили через етилові спирти зростаючої концентрації $i$ поміщали у парафрінові блоки. Мікротомні зрізи товщиною 5-7 мкм після проведення депарафрінізації фрарбували гематоксилінеозином, за Ван Гізоном, Маллорі, Вейгертом, толуїдиновим синім. Проводили морфометрію артерій язика середнього (зовнішній діаметр 51-125 мкм) та дрібного калібрів (зовнішній діаметр - 26-50 мкм). При морфометрії артерій язика визначали їх зовнішній та внутрішній діаметри, товщину медії і адвентиції, висоту ендотеліоцитів, їх ядер, ядерноцитоплазматичні відношення в ендотеліоцитах, індекс Керногана, відносний об'єм пошкоджених ендотеліоцитів. Кількісні 
показники обробляли статистично. В результаті аналізу отриманих морфометричних параметрів виявлено, що з віком більш виражено змінювалися артерії дрібного калібру. У 24-місячних білих щурів зовнішній діаметр артерій язика дрібного калібру зріс всього на 1,2\%, а просвіт зменшився на 4,4\%. Збільшення зовнішнього діаметра досліджуваних судин і зменшення їх просвіту призводило до зміни індексу Керногана, який при цьому статистично значуще (р<0,01) зменшився на 11,8\%. У 24місячних білих щурів виявлено зростання товщини медії вказаних артерій язика на 7,5\%, а товщини адвентиції - на 6,2\%. В експериментальних умовах висота ендотеліоцитів досліджуваних судин зменшилася на 2,4, а діаметр їх ядер - на 3,3\%. Суттєвої різниці між ядерно-цитоплазматичним відношенням у ендотеліоцитах досліджуваних судин язика 8-місячних та 24-місячних білих щурів не виявлено, що свідчило про стабільність структурного клітинного гомеостазу. Відносний об'єм пошкоджених ендотеліоцитів в досліджуваних експериментальних умовах у артеріях середнього калібру зріс на 17,3\%, а дрібного - на 23,7\%, що пояснюється їх віковим апоптозом. Отримані результати свідчать, що з віком виникає структурна перебудова (ремоделювання) переважно артерій язика дрібного калібру, яка характеризується потовщенням їх стінки, звуженням просвіту, зростанням товщини медії та адвентиції. Вікове зменшення індексу Керногана досліджуваних судин свідчить про зниження їх фрізіологічної пропускної здатності та погіршення кровопостачання органа. 3 віком змінюються морфометричні параметри ендотеліоцитів та їх ядер при збереженні структурного клітинного гомеостазу. 3 віком збільшується також відносний об'єм пошкоджених ендотеліоцитів досліджуваних судин. Доведено, що ступінь вікової структурної перебудови артеріального русла язика залежить від діаметра судин.

Ключові слова: вікові особливості, щури, язик, артерії, ремоделювання, морфометрія.

\section{ВОЗРАСТНЫЕ ОСОБЕННОСТИ РЕМОДЕЛИРОВАНИЯ АРТЕРИЙ ЯЗЫКА У ЭКСПЕРИМЕНТАЛЬНЫХ ЖИВОТНЫХ}

Гнатюк М. С., Боднарчук И. В., Татарчук Л.В., Гасюк П. А.

Структурно-фрункциональные особенности языка до сегодняшнего дня привлекают внимание исследователей, которые часто интересуются особенностями структурной организации его артериального русла, что играет важную роль $в$ кровоснабжении и морфогенезе органа при различных повреждениях. Цель исследования - изучить возрастные особенности ремоделирования артерий языка у экспериментальных животных. Материалом исследования были артериальные сосуды языка 30 лабораторных белых крыс-самцов, находившихся в обычных условиях вивария. Экспериментальные животные были разделены на две группы. Первая группа насчитывала 15 интактных практически здоровых животных возрастом 8 мес., вторая - 15 интактных крыс в возрасте 24 мес. Эвтаназия экспериментальных животных осуществлялась кровопусканием в условиях тиопентал-натриевого наркоза. Со средней части языка вырезали кусочки, которые фриксировали в 10\% нейтральном растворе формалина. Указанные кусочки языка проводили через этиловые спирты возрастающей концентрации и помещали в парафриновые блоки. Микротомные срезы толщиной 5-7 мкм после проведения депарафринизации окрашивали гематоксилин-эозином, по Ван Гизону, Маллори, Вейгерту, толуидиновым синим. Проводили морфометрию артерий языка среднего (наружный диаметр 51-125 мкм) и мелкого калибров (внешний диаметр - 26-50 мкм). При морфометрии артерий языка определяли их внешний и внутренний диаметры, толщину медии и адвентиции, высоту эндотелиоцитов, их ядер, ядерно-цитоплазматические отношения в эндотелиоцитах, индекс Керногана, относительный объем поврежденных эндотелиоцитов. Количественные показатели обрабатывали статистически. В результате анализа полученных морфометрических параметров выявлено, что с возрастом более выражено менялись артерии мелкого калибра. У 24-месячных белых крыс внешний диаметр артерий языка мелкого калибра вырос всего на 1,2\%, а просвет уменьшился на 4,4\%. Увеличение наружного диаметра исследуемых сосудов и уменьшение их просвета приводило к изменению индекса Керногана, который при этом статистически значимо (p<0,01) уменьшился на 11,8\%. У 24-месячных белых крыс обнаружено рост толщины медии указанных артерий языка на $7,5 \%$, а толщины адвентиции - на $6,2 \%$. В исследуемых экспериментальных условиях высота эндотелиоцитов исследуемых сосудов уменьшилась на 2,4\%, а диаметр их ядер - на 3,3\%. Существенной разницы между ядерно-цитоплазматическим отношением в эндотелиоцитах исследуемых сосудов языка 8-месячных и 24-месячных белых крыс не обнаружено, что свидетельствовало о стабильности структурного клеточного гомеостаза. Относительный объем поврежденных эндотелиоцитов в исследуемых экспериментальных условиях в артериях среднего калибра вырос на 17,3\%, а мелкого - на 23,7\%, что объясняется их возрастным апоптозом. Полученные результаты свидетельствуют, что с возрастом возникает структурная перестройка (ремоделирование) преимущественно артерий языка мелкого калибра, которая характеризуется утолщением их стенки, сужением просвета, ростом толщины медиа и адвентиции. Возрастное уменьщение индекса Керногана исследуемых сосудов свидетельствует о снижении их физиологической пропускной способности и ухудшении кровоснабжения органа. С возрастом изменяются морфометрические параметры эндотелиоцитов и их ядер при сохранении структурного клеточного гомеостаза. С возрастом увеличивается также относительный объем поврежденных эндотелиоцитов исследуемых сосудов. Доказано, что степень возрастной структурной перестройки артериального русла языка зависит от диаметра сосудов. Ключевые слова: возрастные особенности, крысы, язык, артерии, ремоделирования, морфометрия. 